\title{
The Recent Transformation of Elite Academic and Public Debates
}

My claim is that the religion of the American public has changed in the past fifty years-within the lifetimes of many current participants in these debates. Moreover, the public's view of science as primarily a means of generating facts about nature has similarly changed. These changes have resulted in the current relationship between religion and science being primarily concerned with morality. In this chapter I will show that religion and science conflicts of the past fifty years, as well as sociological theory developments in the same time frame, have already demonstrated the same change-although this has not been recognized by scholars. I cannot demonstrate that the public's new view changed the elite debate or vice versa, but when the information in this chapter is combined with that of the next, we will see that overall the relationship between religion and science has indeed changed.

I first examine the recent history of academic sociology debates that are not about religion and science per se, and are therefore not beholden to existing categories, but which do suggest that sociology is unconsciously moving away from the systemic knowledge conflict perspective. I then turn to the recent history of public debates between elite scientists and theologians, akin to the bulk of historical studies of religion and science, and show that these are primarily about morality, with the religious accepting the knowledge claims of science as true.

Of course, nobody tripped a historical switch in 1967 that transformed society. The antecedents of this moral debate existed for a century, as has been recognized by historians, particularly those examining debates about Darwin. However, since historians do not examine the present, they have largely not seen that these were indeed antecedents of a transformation that is only evident from looking at 
contemporary society. I therefore re-narrate the history of debates over Darwin from a moral perspective.

In the systemic knowledge conflict account, the supposed clash in the seventeenth century between Galileo and the pope over claims about the physical world is a totemic object. To be provocative, the recent conflicts between science and religion described in this chapter will eventually be a replacement for the Galileo account-a shorthand way to say that history shows there has "always" been an "inevitable" conflict between religion and science over morality.

\section{RECENT SOCIAL SCIENCE THEORIES \\ Definitions of Religion That Do Not Focus on Knowledge of Nature}

The definitions of religion that are used when people see types of knowledge conflict are those that see religion as concerning distinctions between "nature" and "super-nature," or, more commonly, the "supernatural." Since science is tasked with explaining nature, this ends up defining religion as that which is not science, thus setting the stage for seeing systemic knowledge conflict. However, since the 1960 s there has been a competing family of definitions of religion which opens the possibility that contemporary religion is not centrally about knowledge-claims about nature. If the authors of these competing theories are reflecting the beliefs of ordinary religious people, this suggests that "religion" is ultimately something that does not clash over knowledge.

There are two dominant traditions in defining religion: the substantive and the functional. ${ }^{1}$ Substantive definitions divide the world into sacred and profane, where the profane world is explicable by human reason. The sacred world operates outside of the power of human reason (e.g., science) to explain it-this is typically called the transcendent or supernatural. Thus, substantive definitions of religion generally "refer to transcendent entities in the conventional sense-God, gods, supernatural beings and worlds, or such metaempirical entities," with Max Weber defining religion as "a cumulative rational systematization of ideas concerning the supernatural." 2

This results in religion being defined as the "irrationalities," as the "not-science." Defining religion as that which is not demonstrable with human reason fits quite well with metaphysical naturalism, and focuses the analyst on claims about the natural and supernatural world. With this definition in hand, religion is about beliefs and knowledge claims, and therefore any conflict with science is bound to be over beliefs and knowledge claims.

This is what religion "is" in the religion and science debate. If religion is based on fact claims about nature, as that which is above or beyond nature, then it is easy to see religion as a failed attempt to explain the natural world. As the new atheists are fond of pointing out, a fundamentalist Protestant exegesis of the Bible makes a 
conflicting fact claim about the natural world — the age of the Earth—and a superior system called science has come along to show that religion is a faulty system of explanation.

In contrast are functional definitions of religion, which became more influential in the 1960s, where religion is any cultural system at its most abstract. Functional definitions of religion identify a religion as that which does certain things for a group of people, independent of content, transcendent, or otherwise. One of the most influential of these definitions among sociologists is that of anthropologist Clifford Geertz, who in the late 1960 s defined religion as "(1) a system of symbols (2) which acts to establish powerful, pervasive, and long-lasting moods and motivations in men (3) by formulating conceptions of a general order of existence and (4) clothing these conceptions with such an aura of factuality that (5) the moods and motivations seem uniquely realistic."3

Geertz further explains each of these elements in his definition. "A system of symbols" is like a program "for the institution of the social and psychological processes which shape public behavior" that is based in a social group. "Moods and motivations" are about how we are supposed to live, our sense of direction, and what we aspire to. Religious symbols "express the world's climate and shape it," shaping it "by inducing in the worshiper a certain distinctive set of dispositions (tendencies, capacities, propensities, skills, habits, liabilities, pronenesses) which lend a chronic character to the flow of his activity and the quality of his experience." Religions formulate "conceptions of a general order of existence," where the entire world and our values make sense. ${ }^{4}$ Creating an "aura of factuality" that makes the "moods and motivations seem uniquely realistic" are, for my purposes, that these socially oriented moods and motivations are come to be thought of as true through social interaction. In this definition, religion is not about knowledge of the natural world.

Others, such as sociologist Peter Berger, published similar and equally influential conceptions of religion during this same era. ${ }^{5}$ Religion in these functional definitions is a combination of understanding the social world and telling us what we should do in the social world. Again, religion is not about facts of nature.

I could be easily convinced that premodern religion concerned fact claims about nature, since surviving in nature was probably central to most people's experience. However, in the contemporary Western world, nature is not the problem for our survival, but our social relationships are. Therefore, using this definition of religion, religion is much more about morality and social relationships than it is about facts. For example, from this perspective on what religion is, while an evangelical will tell you that the Genesis account of creation is true, that does not really matter in their life, and this ritual enactment of this truth actually exists to deliver a social or moral lesson, such as "we are not God." Did Job of the Hebrew Bible and Christian Old Testament exist? Some churches would say yes to this 
fact-claim, but that does not matter to an ordinary congregant as much as the fact that the collective belief in Job teaches the community a social and moral message about suffering.

A study of secularization on a Danish island nicely demonstrates how changing the definition of religion can allow the analyst to see a relationship between religion and science in the public quite differently than has historically been portrayed. Anthropologist Andrew Buckser concluded that the decline in religious activity on the island was not because of science. Rather, it was due to how social relationships on the island had changed due to agricultural mechanization, which had, in turn, reduced the population of villages and weakened social ties. He concludes that the problem with using the then-dominant secularization theory to understand his case is that it uses a definition by which religion is "a method of explaining the physical world through the supernatural." But, he concludes, citing Geertz, that "in any religion, explaining the physical world is only a subordinate task; it is explaining the social world, giving it meaning and moral value, which is religion's primary concern." ${ }^{\prime}$

While the established and older definition of religion was pushing him to see systemic knowledge conflict, by adopting the newer functional definition of religion he saw that any conflict between religion and science was social or moral. To the extent that this definition of religion was generated through observing the most recent religious public, this strand of social science theory suggests that we are right to question whether the contemporary religious public is in knowledge conflict with science.

\section{Questioning Science as Neutral Knowledge}

From the other side of the religion-science relationship, scholarship in the field of the sociology of science evolved in the mid 1970s to challenge the idea that science is a value-free investigation of the truth of nature independent of influence from the social and moral worlds. Intellectually, this was largely a reaction to a Whiggish historiography of science, which portrayed today's scientific truths as inevitably coming to be realized. Sociologists and other academics involved in the nascent field of science studies came to agree with Hegel, who wrote that "truth is not a minted coin which can be given and pocketed ready-made."

One of the basic insights of the late 1970s Edinburgh School of science studies was that social situations and interests influenced the fact claims about nature that are made by scientists. While there is an extremely strong version of this view that suggests that truth does not exist, I think most academics would agree with the milder form, which is that truth does exist, but that human access to truth is limited and influenced by our social relationships. Part of the intellectual strategy of the Edinburgh School was to bracket whether a truth claim was later agreed to be 
true by scientists, and to show how scientists had to use various social mechanisms to convince their colleagues of claims that would eventually be considered true (the double-helix structure of DNA) and false (phrenology).

The early academic statements in this field made the case that the establishment of a scientific knowledge claim as true was a social achievement, not something that would just emerge on its own.7 Severed from the truth of nature, science had to make efforts to establish truth and authority, not unlike how religious leaders had to establish truth and authority. There have been sporadic studies in science studies that do not start with the assumption that the science is correct and the religion is incorrect. For example, one set of studies examined how scientists struggled to demarcate "science" from "non-science," and therefore establish social authority for their knowledge claims. ${ }^{8}$

The eventual term for this academic field-the sociology of scientific knowledge-indicates that while science was still thought of as concerning knowledge, it certainly also was about social relationships and morals, in service of creating authentic knowledge. This field, developed within the past fifty years, reflects the post-196os public skepticism about all institutions, and suggests that the public might not be as confident as they were in the past that scientists are only engaged in the morally neutral discovery of truth about the natural world.

\section{New Secularization Theory Without Systemic Knowledge Conflict}

Recent secularization theory also has shifted away from a focus on knowledge. The classic studies of secularization presumed systemic knowledge conflict-that the growth of certain types of rationality embodied in modern science-were central to secularization. In one summary, "the era of the Enlightenment generated a rational view of the world based on empirical standards of proof, scientific knowledge of natural phenomena, and technological mastery of the universe. Rationalism was thought to have rendered the central claims of the Church implausible in modern societies, blowing away the vestiges of superstitious dogma in Western Europe."9

The most explicit version of this knowledge conflict account of secularization comes from Anthony Wallace, who saw science as directly causing secularization. He wrote that "the evolutionary future of religion is extinction. Belief in supernatural beings and supernatural forces that affect nature without obeying nature's laws will erode and become only interesting historical memory. ... Belief in supernatural powers is doomed to die out, all over the world, as the result of the increasing adequacy and diffusion of scientific knowledge."10

However, a twenty-first-century strand of secularization theory avoids assuming that religion is centrally concerned with knowledge about the world, but focuses on religion as an institution with multiple tasks and interests, struggling against other institutions. The focus here is on power and agency of individuals 
within institutions, and empirical study of public interactions supports a different view that is incompatible with knowledge conflict. Secularization is not the result of a creeping habit of thought but rather due to secularizers-people who have an interest in discrediting religion. ${ }^{11}$ Since it is not science per se that has a secularizing effect, these secularizers do not need to be scientists. For example, journalism as a profession secularized as subjective religious perspectives in newspapers were jettisoned in order for the media to have an impact on public education. ${ }^{12}$

The recent use of rational choice secularization theory also ignores science. This strand of theory was developed as a reflection of social reality-it was developed in part to explain the empirical reality that science had not destroyed religion in the U.S., one of the most scientifically advanced countries in the world. This theory assumes a constant demand for religion from the public, and secularization happens where religious organizations do not effectively meet this demand. ${ }^{13}$ Europe is then more secular than the U.S. because of its religious monopolies, as represented by national churches, which result in lazy, ineffective religious suppliers. America is then more religious because our diverse and competitive religious market maintains efficient religious organizations. ${ }^{14}$ Secularization is then not the result of science.

Even secularization theories that seem based on religion being a faulty understanding of nature have been tweaked to make them not about nature per se, but about the typical human response to nature. For example, Norris and Inglehart created a theory of secularization based on existential security where, in traditional societies, a lack of existential security comes from nature, and thus religion explains nature. However, in the U.S., a lack of existential security comes from society, where people could die due to a lack of healthcare. The existence of religion in the U.S. would then be due to this social threat, and the reason the U.S. has not secularized like Western Europe is, essentially, the absence of a welfare state. Scientific knowledge does not cause secularization per se, rather science causes secularization by allowing for the technology that provides existential security. This appears to be a clear case where a theory reflects society, in that the persistence of religion in the U.S.-in spite of claims that science should have wiped it out-led to a new theory that does not include science per se..$^{15}$

The secularization literature has been the location of much of the sociological work on the relationship between science and religion. The earlier tradition assumes systemic knowledge conflict between science and religion, with an increase in science mechanically leading to a decline in religion. Secularization theories of the past fifty years no longer presume that the decline of religion is due to the spread of scientific knowledge. This suggests that when these theorists examine the contemporary religious public they do not see a religion centrally concerned with knowledge. 
We have extensively examined the historical literature in the previous chapter. How about the recent history of the past fifty years, which is typically not covered by historians? We saw evidence in the previous chapter that when historians more informally shift to discussing the contemporary era, they unreflectively start describing moral conflict, not knowledge conflict. In my examples below, we see conflict that lacks any knowledge component whatsoever, and only concerns morality. These conflicts are often prefigured in earlier periods. If it was true that pre-1960s American religious elites were in conflict with elite scientists over knowledge, I would argue that scientists won that contest, and scientists are now moving on to try to take the one remaining jurisdiction of theologymorals or values.

\section{Scientists Trying to Produce Meaning for Humanity}

What should be the source of the social norms that underpin a society? In the West these underpinnings have been religion. But, at various points in the past 100 years scientists have gained a level of confidence to assert that science should be the source of the norms that undergird society. By the late nineteenth century, a number of elite scientists and other intellectuals had created the rationale for a pseudo-religious "ethic of science" that would replace religion-what intellectual historian David Hollinger calls "the intellectual gospel."16 This ethic of science included disinterestedness, objectivity, universalism, and veracity, and sociologists will recognize the similarity with what Robert Merton in the early 1940 os considered to be the norms of science. ${ }^{17}$ This ethic, epitomized and replicated by the best of the scientific community, could have religious potential for the society. ${ }^{18}$ In one particularly evocative formulation of the advantage of this religion of science, an advocate wrote in 1916 that "the truly scientific mind 'cannot be brought within the bounds of a narrow religious formulary . . y yet it is essentially devout, and it influences for good all with whom it comes into contact." As a popular book written by a biologist stated in 1922, "the scientific habit of mind' would 'satisfy the ethical and philosophical desires which have been hitherto formulated as religion and theology"' ${ }^{19}$ Intellectual historian Andrew Jewett writes that this group "reasoned that, because science carried with it a set of ethical resources, it could ground a democratic culture in the absence of a central religious authority, and thereby take over the core political functions of the pan-Protestant establishment." ${ }^{20}$ Hollinger implicitly endorses my thesis that this moral conflict has largely been ignored by historians when he writes that "the intellectual gospel may not 
have been an episode in any 'warfare' of science and religion, but it did function in a real struggle between rival claimants to the cultural leadership of the United States." ${ }^{21}$ Quite obviously, this has little to nothing to do with knowledge.

There was a very similar elite debate between religion and science from the 1950 s forward that has also not been described as a debate between religion and science. Like the earlier "ethics of science" debate, the reason for its invisibility is probably that it was not about fact claims about nature, but about morality, so it did not fit into scholars' conception of what an actual religion and science debate is.

This 1950 s and 1960 s era debate between theologians, scientists, and others eventually became what is now called the "public bioethical debate." In previous texts I have examined the history of this debate, and what is most important for my present purposes is that I am unaware of any instance in all of that deliberation where a theologian challenged a scientist or physician about a fact claim about the natural world. ${ }^{22}$ Instead, the theologians wanted to discuss either the morality behind, or the moral implications of, the scientists' activity.

Starting in the 1950s, scientists and physicians had made huge progress with the degree to which they could intervene in the human body. Scientists came to think that they would soon be able to engage in mind control, human cloning, human genetic engineering, test-tube babies, parthenogenesis, human/animal chimeras, organ transplantation, and much more. This led to deeper questions, such as what a human was and when would you know someone was actually dead so that you could remove their organs. Some of the elite scientists of the time were not content with making fact claims about nature, but were trying to have science answer the questions that had typically been associated with theology.

As Robert Edwards, co-inventor of in-vitro fertilization would later recall, "many non-scientists see a more limited role for science, almost a fact-gathering exercise providing neither values, morals, nor standards. . . . My answer . . . is that moral laws must be based on what man knows about himself, and that this knowledge inevitably comes largely from science." ${ }^{23}$ Similarly, Jacob Bronowski would state in 1962 that "I am, therefore, not in the least ashamed to be told by somebody else that my values, because they are grounded in my science, are relative, and his are given by God. My values, in my opinion, come from as objective and definitive a source as any god, namely the nature of the human being." ${ }^{24}$ Like the advocates of the "intellectual gospel" before them, elite scientists argued that science could set the morals of society.

Some of the theologians of the time recognized that they were being challenged on moral grounds by biologists. For example, Methodist theologian Paul Ramsey was opposed to some of the planned activities of the scientists on moral grounds, but was primarily opposed to the moral system being promoted by the scientists, recognizing that these scientists posed a challenge to theology's jurisdiction over determining meaning and morality. He was opposed to what he called 
the "surrogate theology" of the "cult" of "messianic positivism" of the scientists. Reacting to scientists like Edwards and Bronowski, he thought the scientists' goal was not to be an "exact science" of knowledge generation, but to provide the meaning of life:

Taken as a whole, the proposals of the revolutionary biologists, the anatomy of their basic thought-forms, the ultimate context for acting on these proposals provides a propitious place for learning the meaning of "playing God"-in contrast to being men on earth.

[The scientists have] "a distinctive attitude toward the world," "a program for utterly transforming it," an "unshakable," nay even a "fanatical," confidence in a "worldview," a "faith" no less than a "program" for the reconstruction of mankind. These expressions rather exactly describe a religious cult, if there ever was one-a cult of men-gods, however otherwise humble. These are not the findings, or the projections, of an exact science as such, but a religious view of where and how ultimate human significance is to be found. It is a proposal concerning mankind's final hope. One is reminded of the words of Martin Luther to the effect that we have either God or an idol and "whatever your heart trusts in and relies on, that is properly your God."25

Scientists soon realized that they had over-reached, and many influential scientists called for an end to scientific claims to remake humanity for fear that such talk would threaten funding for the science that most scientists wanted to do. For example, Harvard bacteriologist Bernard Davis agreed with the other scientists that science had "replaced earlier supernatural and animistic explanations of the universe" and thus "split the rock underlying Judeo-Christian morality." But, the "failure of science to provide a basis for a replacement, underlies much of the tragedy, anxiety, and rootlessness of the present age," precipitating attacks on science. ${ }^{26}$ He began a 1970 article by decrying the statements of influential scientists by arguing that "some of these statements, and many articles in the popular press, have tended toward exuberant, Promethean predictions of unlimited control and have led the public to expect the blue-printing of human personalities." Moreover, the "exaggeration of the dangers from genetics will inevitably contribute to an already distorted public view, which increasingly blames science for our problems and ignores its contributions to our welfare." This "irresponsible hyperbole has already influenced the funding of research." ${ }^{27}$ A few years later he would explicitly reject the moral project of other elite scientists. He wrote that scientists had accepted a "naive" view that "failed to recognize the fundamental distinction between empirical questions, concerned with the nature of the external world, and normative questions, concerned with moral values." ${ }^{28}$

The theologians and others were successful at getting the public focused upon these new moral challenges from the scientists' newfound abilities. They were so successful that they got the attention of the U.S. government, which eventually 
established government ethics commissions that would advise the government on what to allow, stripping direct control from the scientists. This was also the beginning of the end for the theologians' involvement in what would come to be known as public bioethical debate. The ultimate consumer of ethical advice regarding scientific experimentation on the human body was now the government, and therefore this ethics had to be in a bureaucratic and calculable form. Debate turned to thinner questions more amenable to regulation, such as safety and the informed consent of research subjects. Theologians were uninterested in such a debate, wanting to talk about the "big questions," such as what it means to be human and debating what the ends or goals of medicine and science should be. A bureaucratic ethics does not want to debate the ends or goals of medicine but wants to set certain goals or ends as undebatable and then ask whether the scientific activity most efficaciously forwards those goals or ends. The profession of bioethics emerged to serve this role.

My point here is that the history of the field of bioethics reveals an elite, exclusively moral conflict between religion and science that has nothing to do with knowledge about the natural world. The bioethics debate was triggered by the moral stance of scientists and physicians of the 1950 s and 1960s, despite the ideology of science as a knowledge-gathering enterprise, and the scientists had a morality that conflicted with that of the theologians. In the later years of the debate, with the theologians gone, members of the bioethics profession effectively and implicitly forwarded the moral perspective of scientists. Yet, this debate is not generally considered a "conflict between religion and science," because, I would argue, it does not fit our preconception that such debates will be about knowledge. ${ }^{29}$

Other scholars have pointed out that this attempt by some elite scientists to create a religion of science continues to this day. In historian Peter Harrison's analysis, the new atheists argue that "the biological sciences provide the ultimate guide to life's most profound questions." One new atheist writer insists that "questions 'about meaning, morality, and life's larger purpose' are ultimately questions that science, and not religion, can answer." Science, that writer insists, "will gradually encompass life's deepest questions." Richard Dawkins similarly claims "that whereas theology had once provided the wrong answers to questions about the meaning of life, 'the right answers now come from evolutionary science." 30

Harrison's analysis continues with Harvard biologist E. O. Wilson, who similarly claims that "scientific materialism 'presents the human mind with an alternative mythology that until now has always point for point in zones of conflict, defeated traditional religion." Science has finally been able "to provide an alternative account of 'man's place in the universe, relying upon 'the scientific method." Moreover, for Wilson, "it is biology that has become 'foremost in relevance to the central questions of philosophy, aiming to explain the nature of mind and reality and the meaning of life." ${ }^{31}$ 


\section{Transhumanism as a Pseudo-Religion}

A critical component of the debate that birthed bioethics was centered on reform eugenics, advanced by scientists who wanted to perfect the human species through genetic engineering. Theologians were skeptical of this effort. The debate about reform eugenics paused for a few decades because it appeared to be scientifically impossible to modify the human genome in any truly substantive way. ${ }^{32}$ However, after a few decades' pause, a remarkably similar set of eugenic arguments emerged from the "transhumanists." Transhumanism is another example of science that is not solely about knowledge, but has a moral perspective that can conflict with religion.

Transhumanism is the application of technology such as genetic engineering, robotics, nanotechnology, and computers to surpass human limitations. ${ }^{33}$ The central idea is that "the human species can and should transcend itself "by realizing new possibilities' of and for human nature." 34 This imperative to "improve" ourselves is well expressed by British philosopher John Harris, who writes that "taking control of evolution and our future development to the point, and indeed beyond the point, where we humans will have changed, perhaps into a new and certainly into a better species altogether, is 'nothing short of a clear imperative to make the world a better place."'35

Transhumanism is not a movement in the public, but a movement of elite scientists and philosophers. The scientists are the Silicon Valley "visionaries" who want to change the world through technology. For example, human genome mapping pioneer J. Craig Venter recently announced the formation of a company called Human Longevity to, in the words of one newspaper writer, "cheat aging and death." ${ }^{36}$ The cofounder of Human Longevity is Peter Diamandis, who is cofounder and Executive Chairman of Singularity University, a transhumanist educational institution in Silicon Valley. ${ }^{37}$

Transhumanism considers itself to be "the apotheosis of science and technology," and, going further, represents the ultimate form of faith in science-"a secularist project that displaces religion." ${ }^{38}$ In the words of one influential proponent: "fundamental changes in our very natures have become both possible and desirable.... [H] umans could become like gods, and in so doing may put conventional religion out of business. Thus it is in the vital interests of Christianity and the other great world faiths to prevent human technological transformation." ${ }_{39}$

Theologians agree that transhumanism is implicitly religious. Theologian Brent Waters considers transhumanism and Christianity to be "contending salvific religions," and he cites the same idea from Martin Luther that Ramsey cited forty years earlier when arguing with an earlier generation of proponents of scientifically reshaping humanity. Transhumanism is:

not a religion in a formal sense, but as Martin Luther suggests, wherever one places one's confidence is necessarily one's god-or, more broadly, one's object of faith or 
ultimate concern. In this respect, transhumanism and Christianity appear to have a number of similarities, particularly with regard to soteriology and eschatology. Transhumanists and Christians agree, for instance, that the finite and mortal human condition is far from ideal. For transhumanists humans have fallen short of achieving their true potential, whereas for Christians humans have not yet become the kinds of creatures God intends them to be. In response both agree that humans require release from their current condition.... Both agree that death is the final enemy; transhumanists conquer this foe by achieving the immortality of endless time, whereas Christians are resurrected into eternity, where there is no time. ${ }^{40}$

The existence of transhumanism shows the continuation of the moral project of finding meaning and purpose through science, and that this effort is a competitor with religion, not for knowledge claims about nature, but for morality. Again, in this "recent history" of debates between religion and science, there is no debate about knowledge whatsoever.

\section{Scientists' Hidden Moral Projects in Political Campaigns}

Studies of contemporary elite scientists in the public sphere show that they often have a moral agenda and act to forward it-often against religion. Scientists in these campaigns imply that they are simply describing reality in a neutral way, but since these descriptions sound like science, their moral projects largely remain hidden from scholars. However, close studies show that scientists tend to select "neutral descriptions" quite consciously to further a moral agenda.

Public debates about embryonic research are a good example. An analysis of British debates from decades ago shows that the debate was framed as "a conflict between those who wish to enforce unthinking obedience to out-of-date religious beliefs and those who are determined to defend scientists' right to continue their search for truth." Despite this framing, a close academic analysis revealed that the arguments on the two sides "cannot be distinguished in terms of their rationality, their reliance on dogma, or in terms of other features central to the stereotyped contrast between religious and scientific styles of thought." So, in this debate, scientific views portrayed as morally neutral were actually in moral conflict with religious views. ${ }^{41}$

A similar pattern can be seen in recent U.S. debates about embryos. Science studies scholar J. Benjamin Hurlbut shows how in the numerous American bioethics commissions concerning human embryos from the 1970s forward, scientists created scientific descriptions of embryos that implicitly served a particular moral agenda. Hurlbut's best example is the scientists' invention of a new scientific-sounding category of the "pre-embryo" to distinguish it from the "embryo." The "pre-embryo" could still twin, but why this trait matters is obviously moral and not based on facts. More importantly, with "embryo" distinguished from 
"pre-embryos", research on "pre-embryos" could proceed apace, which is something that the scientific community was interested in doing. Similar efforts were made by scientists to change the terms used in the cloning debate from "cloned embryo" to "therapeutic cloning" (to distinguish from "reproductive cloning"). Later cloning would be relabeled "somatic cell nuclear transfer," which avoids the "cloning" term altogether. Scientists tried to take the same ontological objectthe cloned embryo-but create different terms based upon people's intended uses of the object-therapy or reproduction. This is not a description of nature, but a distinction based on people's intentions, with some uses being implicitly moral or immoral. ${ }^{42}$

Hurlbut also examines the political debate in California surrounding Proposition 71, which proposed to have the state of California spend three billion dollars on embryonic stem cell research and explicitly allow the use of cloned embryos to produce stem cells (but not produce babies). It is hard to imagine that any citizen of California would think after this campaign that scientists were merely producing facts about nature. Rather, elite scientists campaigned for political positions that were consistent with their moral agenda. ${ }^{43}$

To start with the obvious, Proposition 71 was centrally about ethics. It implicitly took a position on the moral status of human embryos, which was that they were not as important as potential medical treatments that could come from embryonic stem cell research. Moreover, three billion dollars of state money was three billion that was not spent on schools, roads, and health care that used currently available technology. To say that California should spend three billion dollars on medical research is a moral choice-a moral choice that a majority of the voting citizens of California eventually agreed with.

The campaign to pass Proposition 71, which involved many scientists, was also not about scientific facts. Whereas some people questioned whether cures would come as fast as the scientists implied, nobody claimed that scientists do not know how stem cells work or that the opponents of the proposition had better fact claims about nature. The campaign was, as political campaigns are, about moral choices.

The beginnings of the campaign were meetings with Hollywood couples who had children with Type 1 diabetes, wealthy disease research advocates, public officials, and prominent stem cell scientists. They saw an opportunity in using California's ballot initiative process, and a coalition formed around this project. The campaign suggested that all Californians would benefit from stem cell research because over 70 different diseases and injuries could be cured with stem cells. ${ }^{44}$

Scientists played a central public role because they had the credibility to say that this research would indeed cure disease. Stanford stem cell biologist Irving Weissman said during a TV interview that scientists could make human embryonic stem cell lines that "represented each and every human disease" and that "the chances of disease to be cured by stem cell research are high, but only if we start." 
In television ads for the campaign, Nobel laureate Paul Berg described the research as "an important scientific and medical breakthrough." University of California San Francisco diabetes expert Jeff Bluestone said that he was "absolutely confident" that stem cells would cure Type 1 diabetes. ${ }^{45}$

While the scientists were making claims within their area of expertise concerning whether this technology would work, more importantly for this book, many of these scientists portrayed themselves as being in conflict with religion. Many religious organizations opposed Proposition 71 , and the motivation for the proposition in the first place was the perception that federal funding for this research had been blocked by religious conservatives' influence on the Republican Party. As an advocate testified in one of the public hearings, it "was the responsibility of the state of California to rectify the failure of the Bush administration to fund embryonic stem cell research," which was the result of "an administration that has ignored science and all its potential in favor of politics and religious extremism." ${ }^{46}$

The scientists did not challenge religion for making false claims about nature, but instead invoked past supposed conflict between religion and science over nature to say why religious morality was also wrong. As we would expect from earlier pages of this book, Galileo was the favored symbol for the scientists. Consider a special issue of the Stanford Medical Magazine. Hurlbut concludes that "the image and the majority of the articles . . . characterized the political battle as a struggle between the antimodern, antidemocratic forces of religion and the enlightened, secular democratic forces of science." The Dean of the Stanford Medical School wrote of the conflict that "it's as if we have entered a time warp, and are spectators at the Inquisition's reading of charges against Galileo for his view of the solar system." 47

In a 2002 hearing on stem cell research, the president of an advocacy organization for California's biomedical industry said that "much of the opposition is rooted in a set of particular religious worldviews." Moreover, "historically religion has not been the handmaiden of science and scientific progress ... Now, on the left is someone you all know-Galileo. On the right is Pope Paul the Fifth, who's not much remembered, except in his role in the Inquisition and the containment, if you will, of Galileo's astronomical ideas.” Similarly, Stanford's Nobel laureate Paul Berg gave a talk titled "Stem Cells: Shades of Galileo." 48

What is striking in all of the references to Galileo is that scientists are not just using Galileo to justify their role as the preeminent observers of nature, as I described in Chapter 2, but in this case to say that their morality is superior to religious morality. In sum, embryonic stem cell research has probably been the most recent, highly publicized clash between religious and scientific elites, and it was over morality, not knowledge. 


\section{ELITE PUBLIC DEBATES ABOUT DARWINISM HAVE BEEN ABOUT MORALITY NOT KNOWLEDGE}

It is important to renarrate the debate about Darwin from my perspective because this debate is thought of as conclusive evidence for the systemic knowledge conflict perspective. The debate about Darwin is also the most prominent debate between contemporary religion and science for the public. ${ }^{49}$

Again, I am not the first to note the moral nature of debates about Darwin. For example, historian Peter Harrison notes that "what religiously motivated antievolutionists fear is not the 'science' as such, but the secularist package of values concealed in what they perceive to be the Trojan horse of evolutionary theory."50 Rather, the moral narrative is usually submerged beneath a surface-level knowledge conflict narrative, and I want to highlight the moral.

For scientific elites this debate is about knowledge-they say we should look at the fossil record to look where humans came from, whereas conservative Protestants supposedly look to their Bibles to see where humans came from. There are of course conservative Protestants who do look to their Bibles for a knowledge claim about the origins of humans, and most would probably say they do so if asked. My point is not that they do not state a belief in knowledge conflict, but rather that if it were not for the moral conflict over Darwin they would not bother to raise the knowledge conflict. The moral conflict is the controlling force here, and the knowledge conflict is subsidiary to it. Moreover, as these debates have progressed over time, they reveal religious activists both making fewer religiously based fact claims and their growing acceptance of the epistemology of science. What is left for the religion side of the debate is a concern with the moral.

While such varied positions as Young Earth Creationism, Old Earth Creationism, Day-Age Creationism, Gap Creationism, Progressive Creationism, and Intelligent Design can be more or less treated as "creationist," it is their qualities as moral criticisms of Darwinism that most tightly bind them together, both historically and sociologically speaking. The concern of creationists in each of their historic incarnations is that when you teach evolution, you are implicitly teaching a certain philosophy at the same time, and that this philosophy undermines some forms of morality.

At the same time, Darwinism has often been the grounds for making moral claims by scientists. It is not that religious challenges erroneously mix morality and science because challengers don't understand science. Rather, challengers understand full well that scientists are also making moral claims, and are acting to counter these claims-and thus we have moral conflict. This contrasts sharply with the self-image of scientists in which they pursue knowledge in a value-free manner. 


\section{The Young Earth Creationist Scopes Trial Era}

I will highlight these points by reviewing the history of debates about Darwin, broken into three eras. After the publication of The Origin of Species in 1859, both supporters and critics recognized that Darwinism had moral implications, a concern that became even more prominent following the publication of the Descent of Man in 1871. Scholar of Victorian literature Gowan Dawson concludes that "it was regularly avowed that the growing licentiousness of modern culture . . . actually gave warning of the repulsive direction in which society was being taken by the increasingly influential doctrines of Darwinism." One of the most problematic components of Darwin's theory for Victorian moral sensibilities was that the 1871 book noted "that the 'whole process of . . . the reproduction of the species, is strikingly the same in all mammals,' even down to 'the act of courtship by the male,' who, whether baboon or human, responded similarly to the smell and appearance of the opposite sex." This led to the "disquieting" implication of "rooting human sexuality in animal behavior." ${ }^{11}$ While philosophers might question the simple move from "is" to "ought," it is clear that for many contemporaries, Darwinism implied some moral challenges, especially when articulated in Herbert Spencer's terms as "survival of the fittest."

In America, concerns over moral implications of Darwinism led to legal restrictions on the teaching of evolution in public schools. ${ }^{52}$ Biology textbooks of the time, such as the popular A Civic Biology by George William Hunter, often contained only a limited amount of material on evolution. But even that limited amount discussed moral problems. A Civic Biology, for example, suggested that "if the stock of domesticated animals can be improved, it is not unfair to ask if the health and vigor of the future generations of men and women on the earth might not be improved by applying to them the law of selection." ${ }^{33}$ That is, the book promoted eugenics. ${ }^{54}$

In May 1925, in order to test the constitutionality of an anti-evolution law, the American Civil Liberties Union provoked the State of Tennessee into prosecuting high school science teacher John Scopes for teaching the evolution lessons from A Civic Biology in a public school classroom. Creationists saw an opportunity to demonstrate that Darwinism implied an unacceptable and dangerous moral position that should not be publicly considered at all, much less taught to schoolchildren. ${ }^{55}$ The defender of the creationist view was populist former Democratic Party presidential candidate William Jennings Bryan. According to Ron Numbers' canonical analysis of creationism, for Bryan:

World War I . . exposed the darkest side of human nature and shattered his illusions about the future of Christian society. Obviously something had gone awry, and Bryan soon traced the source of the trouble to the paralyzing influence of Darwinism on the conscience. By substituting the law of the jungle for the teachings of Christ, 
it threatened the principles he valued most: democracy and Christianity. Two books in particular confirmed his suspicion. The first . . recounted firsthand conversations with German officers that revealed the role of Darwin's biology in the German decision to declare war. The second ... purported to demonstrate the historical and philosophical links between Darwinism and German militarism. ${ }^{56}$

According to historian Mark Noll, Bryan's “strident opposition to evolution arose not so much from a threat to traditional interpretations of Genesis 1 but because evolution threatened human dignity. A godless theory of evolution . . . would, if generally adopted, destroy all sense of responsibility and menace the morals of the world." Moreover, Bryan "saw clearly that the greatest problem with evolution was not the practice of science but the metaphysical naturalism and consequent social Darwinism that scientific evolution was often called upon to justify." ${ }^{7}$

In the late paleontologist Steven J. Gould's turn-of-the-twenty-first-century assessment, when Bryan "said that Darwinism had been widely portrayed as a defense of war, domination, and domestic exploitation, he was right." 58 According to historian Edward Larson, "many Americans associated Darwinian natural selection, as it applied to people, with a survival-of-the-fittest mentality that justified laissez-faire capitalism, imperialism, and militarism." Reflecting his decades in politics defending the common man, Bryan would in 1904 dismiss Darwinism as "the merciless law by which the strong crowd out and kill off the weak." Larson concludes that "everywhere the public debate over eugenics colored people's thinking about the theory of human evolution." 59 It appears that the most famous opponent of Darwinism was not primarily motivated by the debate about facts.

Indeed, it has been argued that the law that John Scopes violated, signed by the Tennessee governor in 1925, was not even motivated by the evolution issue, but the evolution issue became a totemic symbol of the larger issue of the declining rural life in the state. The content of high school biology of the time is summed up with the title of the book Scopes was accused of using: Civic Biology. "Civic Biology, with its focus on such issues as quarantine, alcohol, food safety, and the improvement of human society (including a substantial section on eugenics), was geared toward America's growing cities," writes historian Adam Shapiro. Indeed, the new curriculum began in New York City. He concludes that "many rural residents saw the expansion of public education in Tennessee as an attempt to change their culture and to instill foreign values. Civic biology taught students to prepare for a life away from their traditional upbringing. Consequently, parents took exception to the presence of biology as well as its content. The fact that the books taught the historical development of species was a small concern. The overall discipline of civic biology and the presence of new schools intended to bring social progress were much more objectionable." ${ }^{\circ}$

The Scopes case drew immense attention as a clash over questions of religion and morality. ${ }^{61}$ Though technically Bryan won the case, creationists failed to 
win public support for their moral concerns. In popular culture, the creationists emerged from the Scopes trial as ignorant bumpkins, while evolution supporters came across as proponents of reason and science. These impressions were solidified by the 1960 Academy Award-nominated film depicting the Scopes trial named Inherit the Wind. ${ }^{62}$

But while it seemed that Darwinism had triumphed in the popular imagination, the empirical fact is that the teaching of evolution in public high schools, and the inclusion of Darwin in biology textbooks, actually declined after the Scopes era, be it due to the trial itself or the anti-evolution movement. Textbook publishers voluntarily self-censored their materials in order to avoid offending dominant sentiments. ${ }^{63}$ For all of the flash of the Scopes trial, there was little interest in, and much public resistance to, expanding the teaching of evolution in public schools.

Without Darwinism moving into the sphere of public morality through the education system, creationists kept to themselves and their own organizations after Scopes. Creationists still worried about the moral claims of Darwinism, but by and large kept their arguments within the creationist community rather than public debate. ${ }^{64}$

Continuing across this era was the eugenics movement, a scientific effort that tried to implement a particular moral vision. In the $19^{\text {th }}$ century Francis Galton, a half-cousin of Darwin, drew heavily on Darwin's theories to promote eugenics, the systematic intervention into human reproduction for the purpose of improving "racial hygiene." ${ }^{65}$ Of concern to many proponents of eugenics was the idea that society could succumb to degeneration, making it less fit for survival and therefore doomed to extinction. Yet many were confident that Darwinism provided the answer. As John Haycraft said in his lectures to the Royal College of Physicians in 1895: "We can improve our race by adopting the one and only adequate expedient, that of carrying on the race through our best and most worthy strains. We can be as certain of our result as the gardener who hoes away the weeds and plants good seed, and who knows that he can produce the plants he wants by his care in the selection of the seed." ${ }^{66}$

Early American eugenics drew on Spencer, Darwin, and Galton to justify programs of forced sterilization for "mental defectives," "moral degenerates," and other "undesirables" to prevent the inheritance of their bad traits to later generations. The Eugenics Record Office, founded in 1910 at the Cold Spring Harbor Laboratory, promoted forced sterilization as good public policy ${ }^{67}$ By 1930 , half of the states in the U.S. had some sort of eugenic sterilization law on the books. In Arizona, inmates of the State Hospital for the Insane could be sterilized if they were the "probable potential parent of socially inadequate offspring," and in Kansas any inmate of the state, including prisoners, could be sterilized if "procreation by him would be likely to result in defective or feeble-minded children with criminal 
tendencies." ${ }^{38}$ Often, however, "degenerate" meant nonwhite or immigrant. By 1924, the U.S. Congress passed the Immigration Reform Act, setting quotas for immigrants according to their seeming fitness and levels of "social inadequacy." Immigration levels did not recover until the late 1980 s. $^{69}$

Of course, the most severe example of eugenics was the systematic sterilization and extermination of those deemed degenerate by the Nazi regime, particularly embodied by the 1933 Law for the Prevention of Genetically Diseased Offspring. The Nazis "regularly quoted American geneticists who expressed support for their sterilization policies ... [and] frequently invoked the largescale California experience with sterilization," writes historian Diane Paul. ${ }^{70}$ It is clear that Nazi policies drew on ideas about racial hygiene and degeneracy, and it is clear that many American scientists admired such firm policies. Of course, the use of Darwin's ideas to legitimate prejudices reached its apotheosis in the Holocaust where, in Kevles' words, "a river of blood would eventually run from the [German] sterilization law of 1933 to Auschwitz and Buchenwald." ${ }^{71}$ Of course, the point is not that Darwin would have approved, but rather that these immoral acts were being justified by others by referencing Darwin's ideas.

\section{Creation Science Era}

With the launch of Sputnik in 1957, the American government turned to funding science education in a concerted and systematic way. The Biological Sciences Curriculum Study brought together, perhaps for the first time, practicing scientists and practicing teachers to create a biology curriculum to be used in the nation's public schools. ${ }^{72}$ The Biological Sciences Curriculum Study program made Darwinism, and evolution more generally, the cornerstone of biology education in America.

In response to the increase in teaching of Darwinism in public schools, creationists mounted challenges to Biological Sciences Curriculum Study textbooks on many different grounds, including indecency of images depicting reproductive organs, violation of remaining state anti-evolution laws, and violation of the First Amendment. ${ }^{73}$ The tactics varied in their approaches, but the common concern remained that Darwinism had dangerous moral implications and should not be taught in schools.

One of the strongest challenges came from "creation science," where creationists dismissed Darwinism based on scientific claims stemming from the Bible. Creation science proponents agreed that students should learn science, but not that they should learn Darwinism. In 1961, Whitcomb and Morris published The Genesis Flood, an account of geology and human origins based on Biblical explanations of the world-girdling Noachic flood. 
For Whitcomb and Morris, the claim to being engaged in science was as much about the need to replace Darwinian morality with a God- and human-centered morality as it was about floods and geology. In The Genesis Flood, they wrote:

The morality of evolution, which assumes that progress and achievement and "good" come about through such action as benefits the individual himself or the group of which he is a part, to the detriment of others, is most obviously anti-Christian. The very essence of Christianity is unselfish sacrifice on behalf of others, motivated by the great sacrifice of Christ himself, dying in atonement for the sins of the whole world! ${ }^{44}$

These sentiments were echoed by local activists, such as one group that distributed a flyer with a pictorial diagram of the "evolution tree" of "evil fruits" growing from the root of Darwinism. These "evil fruits" include (but are not limited to) communism, racism, terrorism, abortion, socialism, crime, and inflation. The accompanying text concludes "What is the best way to counteract the evil fruit of evolution? Opposing these things one-by-one is good, but it does not deal with the underlying cause.... A more effective approach is to chop the tree off at its base by scientifically discrediting evolution." 75

In 1968, the decision in Epperson v. Arkansas rendered anti-evolution laws unconstitutional. In 1974 Morris produced Scientific Creationism, a guide to teaching creation science without explicit reference to biblical authority or even religious language. ${ }^{76}$ Without the advantage of anti-evolution laws, creationists promoted the idea of "equal time" and "balanced treatment" for creation science and Darwinian science, and even obtained legal protection for such treatment in Arkansas and Louisiana. ${ }^{77}$

In 1982, however, McLean v. Arkansas marked the beginning of the end for creation science in public science classes. The McLean decision struck down the Arkansas law on the basis that creation science violated the American Constitution's First Amendment prohibition on the establishment of religion. The judge acknowledged that creation science was in part a reaction to the introduction of the Biological Sciences Curriculum Study curriculum, even citing the moral concerns driving the challenge in the official opinion: "Creationists view evolution as a source of society's ills [and that] it has served effectively as the pseudo-scientific basis of atheism, agnosticism, socialism, fascism, and numerous other false and dangerous philosophies over the past century." ${ }^{38}$

Yet the judge focused his legal decision on knowledge issues, itemizing the ways in which creation science did not accord with scientific method or practice, and emphasizing that creation science was not, in his opinion, science at all. While this was not strictly necessary for rendering an opinion on the religious grounds for creation science, it nonetheless reinforced the perception in the public sphere of systemic knowledge conflict. From McLean forward, the success of creationist challenges would be measured based on whether or not creationist theories were included in "science" 
as defined by judges in landmark legal cases, rather than the extent to which moral concerns resonated with a broader public. In 1987, Edwards v. Aguillard came before the U.S. Supreme Court, and-largely based on the reasoning about the establishment of religion in McLean - the court rendered a decision to strike down Louisiana's Creationism Act, the last remaining "equal time" law in the nation.

The centrality of morality to conservative Protestant anti-evolution movements up through the creation science era is summarized by anthropologist Christopher Toumey, who wrote that "creationism is a moral theory that the idea of evolution is intimately involved in immorality, as cause or effect or both." It is "much more than a narrow doctrine extrapolated from a handful of biblical verses. It represents a broad cultural discontent, featuring fear of anarchy, revulsion for abortion, disdain for promiscuity, and endless other issues, with evolution integrated into those fears."79

\section{The Intelligent Design Era}

McLean and Edwards instituted a legal regime wherein any hint of religious motivations could invalidate an attempt to promote an alternative to Darwinism. In response, advocates reworked an existing creation science textbook to remove all references to creationism and replace them with the term "intelligent design" (ID). They published the resulting text in 1989 as Of Pandas and People. ${ }^{80}$ The term "ID" refers to the idea that the world we observe is so complex that it could not have arisen without intelligent guidance, an idea that traces its roots back to Isaac Newton and William Paley. ${ }^{81}$ Notably, however, ID does not necessarily require specific claims about God or a particular religious belief system.

The most visible and active proponents of ID are fellows of the Discovery Institute, and their strategy for promoting ID is revealed in the "Wedge Document," a text originally intended for internal use, but copied and widely circulated by opponents seeking to discredit ID. The Wedge Document cites as motivation for ID the serious moral concerns implied by the materialist conception of reality promoted by Darwinism, which:

eventually infected virtually every area of our culture, from politics and economics to literature and art ... materialists denied the existence of objective moral standards, claiming that environment dictates our behavior and beliefs. Such moral relativism was uncritically adopted by much of the social sciences. . . Materialists also undermined personal responsibility by asserting that human thoughts and behaviors are dictated by our biology and environment ... In the materialist scheme of things, everyone is a victim and no one can be held accountable for his or her actions. ${ }^{82}$

As with creation science, ID proponents seek equal time for their position in public school science classes. Unlike creation science advocates, ID proponents take special care to minimize the possibility that ID will be seen as religious. So 
far, this strategy has met with limited success. In 2004, a school board in Dover, Pennsylvania voted to require a statement about ID as part of the public school curriculum. Shortly thereafter, a group of parents filed suit against the district, and the resulting decision, in Kitzmiller v. Dover, once again struck down a creationist challenge based on the First Amendment Establishment Clause.

ID proponents have once again taken up the idea of "equal time" and "teaching the controversy," but in the public rather than the legal arena. A documentary film titled Expelled: No Intelligence Allowed claims that alternatives to Darwinism have been suppressed, and that Darwinism is of grave moral concern. An accompanying text for the documentary claims that "In a Darwinian framework, human beings are no better than any other animal and ultimately may be treated as animals by those who consider themselves to be greater, more human, enlightened or evolved ... Hitler and the Nazis followed Darwinian eugenics to an extreme, carrying 'survival of the fittest' to the radical conclusion of exterminating 'unfit' and 'inferior' races like the Jews and Gypsies, and 'weak' members of society like the handicapped." ${ }^{3}$

Unsurprisingly, reaction to ID from defenders of science in popular and academic venues has focused on ID's religious origins, as this is now the most effective legal way to prevent ID from inclusion in public school curricula. ${ }^{84}$ However, the central claim at the heart of ID remains consistent with Bryan, Whitcomb, and many other creationists since Darwin. For creationist challengers past and present, Darwinism implies a morality that devalues human life, causes unneeded conflict and competition, and pushes society in an actively harmful direction. Religion and science debates about Darwin are largely moral.

\section{CONCLUSION}

In the previous two chapters I have shown how those who write about the relationship between religion and science presume a systemic knowledge conflict between religion and science. In this chapter I have examined contemporary social science definitions of religion, secularization theory and the sociology of science. These should in principle be at least somewhat based on contemporary American society, and these do not portray religion and science as in systemic knowledge conflict.

As I showed in the last chapter, historical studies of conflict between elite representatives of religion and science largely show systemic knowledge conflict. In this chapter I examined the recent history of the past fifty years or so-debates that evolved into modern bioethics, transhumanism, and scientists' political activism. All show moral and not knowledge conflict. Finally, I re-narrated the history of conflict over Darwin. This debate is particularly significant because it is really 
the only religion and science conflict today that is conceivably about knowledge claims. I show that this debate has always been largely moral.

In Chapter 6, I will present my own data analyses concerning the contemporary public. In this chapter, by showing that even contemporary elites-who are prone to seeing science and religion as structures of knowledge-do not see religion and science as arguing about knowledge, I have bolstered my interpretation in that later chapter. Before starting that analysis, I turn in the next chapter to existing research on the general public, which also should make us skeptical that ordinary religious people are in systemic knowledge conflict with science and suggests it is likely that they are instead in moral conflict with science. 